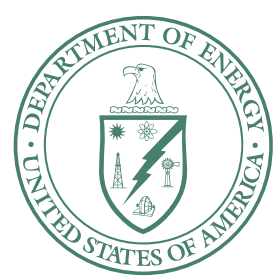

U.S. Department of Energy

Idaho Operations Office

\title{
Operable Unit 3-13, Group 3, Other Surface Soils Remediation Sets 4-6 (Phase II) Waste Management Plan
}

July 2006 
DOE/ID-11258

Revision 0

Project No. 23083

\section{Operable Unit 3-13, Group 3, Other Surface Soils Remediation Sets 4-6 (Phase II) Waste Management Plan}

July 2006

Prepared for the 



\begin{abstract}
This Waste Management Plan describes waste management and waste minimization activities for Group 3, Other Surface Soils Remediation Sets 4-6 (Phase II) at the Idaho Nuclear Technology and Engineering Center located within the Idaho National Laboratory. The waste management activities described in this plan support the selected response action presented in the Final Record of Decision for Idaho Nuclear Technology and Engineering Center, Operable Unit 3-13. This plan identifies the waste streams that will be generated during implementation of the remedial action and presents plans for waste minimization, waste management strategies, and waste disposition.
\end{abstract}




\section{CONTENTS}

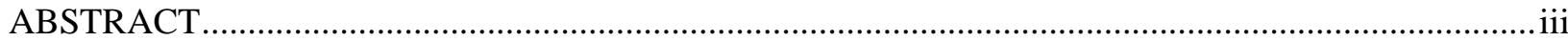

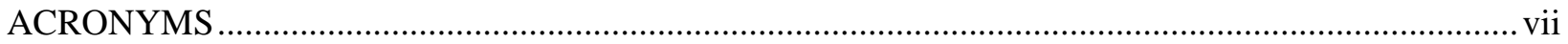

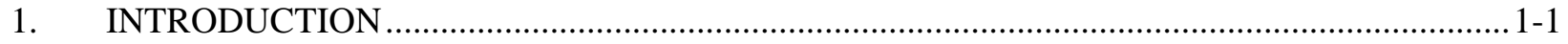

1.1 Purpose and Objectives .................................................................................... $1-1$

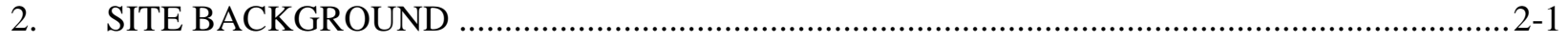

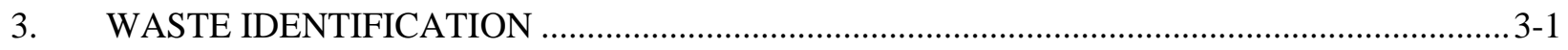

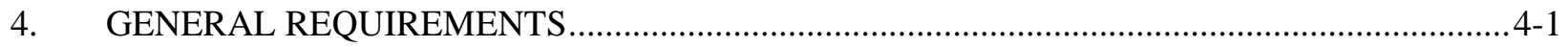

4.1 Waste Minimization and Segregation......................................................................... 4-1

$4.2 \quad$ Characterization Strategy ….................................................................................. $4-1$

4.3 INL Waste Management and Disposition ................................................................ 4-2

4.3.1 Waste Planned for Disposal at the ICDF .................................................. 4-2

4.3.2 Waste Transported to Non-INL Facilities ......................................................... 4-2

4.3.3 Waste Planned for Disposal at Non-CERCLA INL Facilities .......................... 4-2

4.3.4 Managing Industrial Waste for Disposal at the INL Landfill Complex........... 4-3

4.3.5 Waste Packaging and Transportation ...............................................................4-3

4.3.6 Managing Waste Information........................................................................ 4-3

4.3.7 Staging, Inspection, and Recordkeeping ..................................................... 4-4

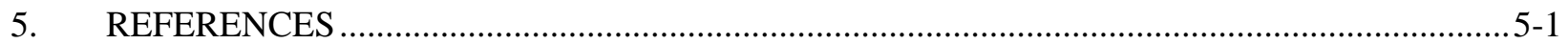

\section{FIGURES}

2-1. Location of the Idaho National Laboratory .........................................................................2-2

2-2. Location of OU 3-13, Group 3, Other Surface Soils, Remediation Sets 4-6 (Phase II).................2-3

\section{TABLES}

3-1. Waste management during OU 3-13, Group 3, Other Surface Soils, Remediation Sets 4-6 (Phase II) remediation activities 


\section{ACRONYMS}

CERCLA Comprehensive Environmental Response, Compensation and Liability Act

CFA Central Facilities Area

CPP Chemical Processing Plant

DOE U.S. Department of Energy

FSP Field Sampling Plan

ICDF Idaho CERCLA Disposal Facility

INL Idaho National Laboratory

INTEC Idaho Nuclear Technology and Engineering Center

IW industrial waste

IWTS Integrated Waste Tracking System

LLW low-level waste

MLLW mixed low-level waste

OU Operable Unit

PCB polychlorinated biphenyl

PPE personal protective equipment

RCRA Resource Conservation and Recovery Act

TSCA Toxic Substance Control Act

WAC Waste Acceptance Criteria

WGS Waste Generator Services

WMP Waste Management Plan 


\section{Operable Unit 3-13, Group 3, Other Surface Soils Remediation Sets 4-6 (Phase II) Waste Management Plan}

\section{INTRODUCTION}

This Waste Management Plan (WMP) was prepared for the Idaho Nuclear Technology and Engineering Center (INTEC) Idaho Cleanup Project at the Idaho National Laboratory (INL). This WMP provides guidance for waste management necessary to identify disposal criteria for waste materials associated with the Operable Unit (OU) 3-13, Group 3, Other Surface Soils Remediation Sets 4-6 (Phase II) plus any additional soil contamination sites to be added to Group 3 under the process detailed in Section 1.3.3 in the Phase II Remedial Design/Remedial Action (RD/RA) Work Plan (DOE/ID-11254).

\subsection{Purpose and Objectives}

This WMP is intended to provide a tool for identifying and managing the waste streams generated from the OU 3-13, Group 3, other surface remediation activities as described in the Phase II RD/RA Work Plan (DOE/ID-11254). The primary objective of this WMP is to properly identify the waste types that are anticipated to be generated during implementation of the Group 3 remedial actions and present a strategy for managing them compliantly. 
1-2 


\section{SITE BACKGROUND}

The INL is a government facility managed by the U.S. Department of Energy (DOE) located $51.5 \mathrm{~km}$ (32 mi) west of Idaho Falls, Idaho. It occupies 2,305 km² $\left(890 \mathrm{mi}^{2}\right)$ of the northeastern portion of the Eastern Snake River Plain. INTEC is located in the south-central portion of the INL as shown in Figure 2-1.

The INTEC Facility, formerly the Idaho Chemical Processing Plant, began operating in 1952. The primary missions were reprocessing uranium for defense purposes and researching and storing spent nuclear fuel. Irradiated defense nuclear fuels were reprocessed to recover unused uranium. In 1992, the reprocessing mission was phased out. The current INTEC mission is receiving and temporarily storing spent nuclear fuel and radioactive waste for future disposition.

Under the FFA/CO, the INEEL was divided into 10 WAGs and INTEC was designated as WAG 3. In turn, WAG 3 was then divided into seven groups of which Group 3 was entitled, "Other Surface Soils." The Group 3, Other Surface Soils sites consist of 29 of the 55 OU 3-13 release sites that required remedial action. These 29 sites were divided into six remediation sets, as documented in the Operable Unit 3-13, Group 3, Other Surface Soils, Prioritization and Site Grouping Report (DOE-ID 2002a), which presents the criteria analysis used to determine how the Group 3 sites were grouped together and prioritized for remediation. Because some Group 3 release sites overlap and/or extend under buildings or structures, they were evaluated for phased remediation to remove high-risk contaminated soils that are not under buildings and place them in a lower-risk configuration in the INEEL CERCLA Disposal Facility (ICDF). Using the criteria developed in the report, the sites were grouped into the following six sets identified in order of decreasing priority:

1. Sites with planned use potential within 10 years

2. Sites with planned use potential beyond 10 years

3. Easily accessible sites with moderate environmental risk reduction

4. Sites east of Chemical Processing Plant (CPP) -603 with significant environmental risk reduction

5. Sites in the Waste Calcining Facility area with high environmental risk reduction, but significant INTEC coordination issues

6. Sites with no planned use and minimal environmental risk reduction.

Sets 1, 2, and 3 were identified, discussed, and are to be remediated under the Operable Unit 3-13, Group 3, Other Surface Soils Remediation Sets 1-3 (Phase I Remedial Design/Remedial Action Work Plan (DOE/ID-11089) as Phase I of the OU 3-13, Group 3, Other Surface Soils, remediation project. Sets 4, 5, and 6 are identified, discussed and are to be remediated under the Phase II work plan (DOE/ID-11254) and are the soil sites associated with this WMP. Remediation Sets 4-6 consist of the following sites, as shown in Figure 2-2:

$\underline{\text { Remediation Set } 4 \text { (Sites East of CPP-603 with Significant Environmental Risk Reduction) }}$

- $\quad$ CPP-01, Concrete Settling Basins and Dry Wells East of CPP-603

- $\quad$ CPP-04/05, Contaminated Soil Area Around CPP-603 Settling Tank and Settling Basin 


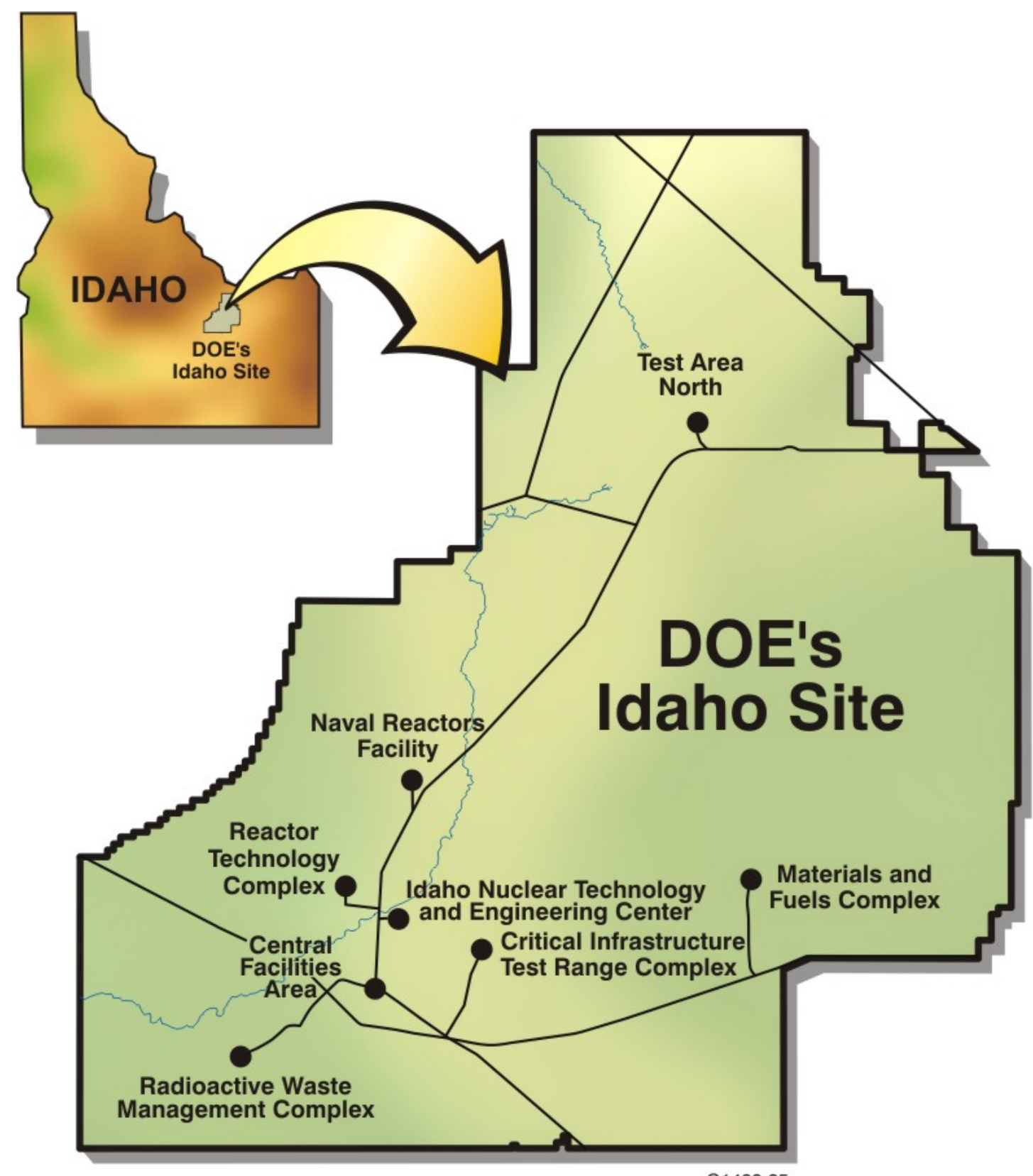

G1422-25

Figure 2-1. Location of the Idaho National Laboratory. 


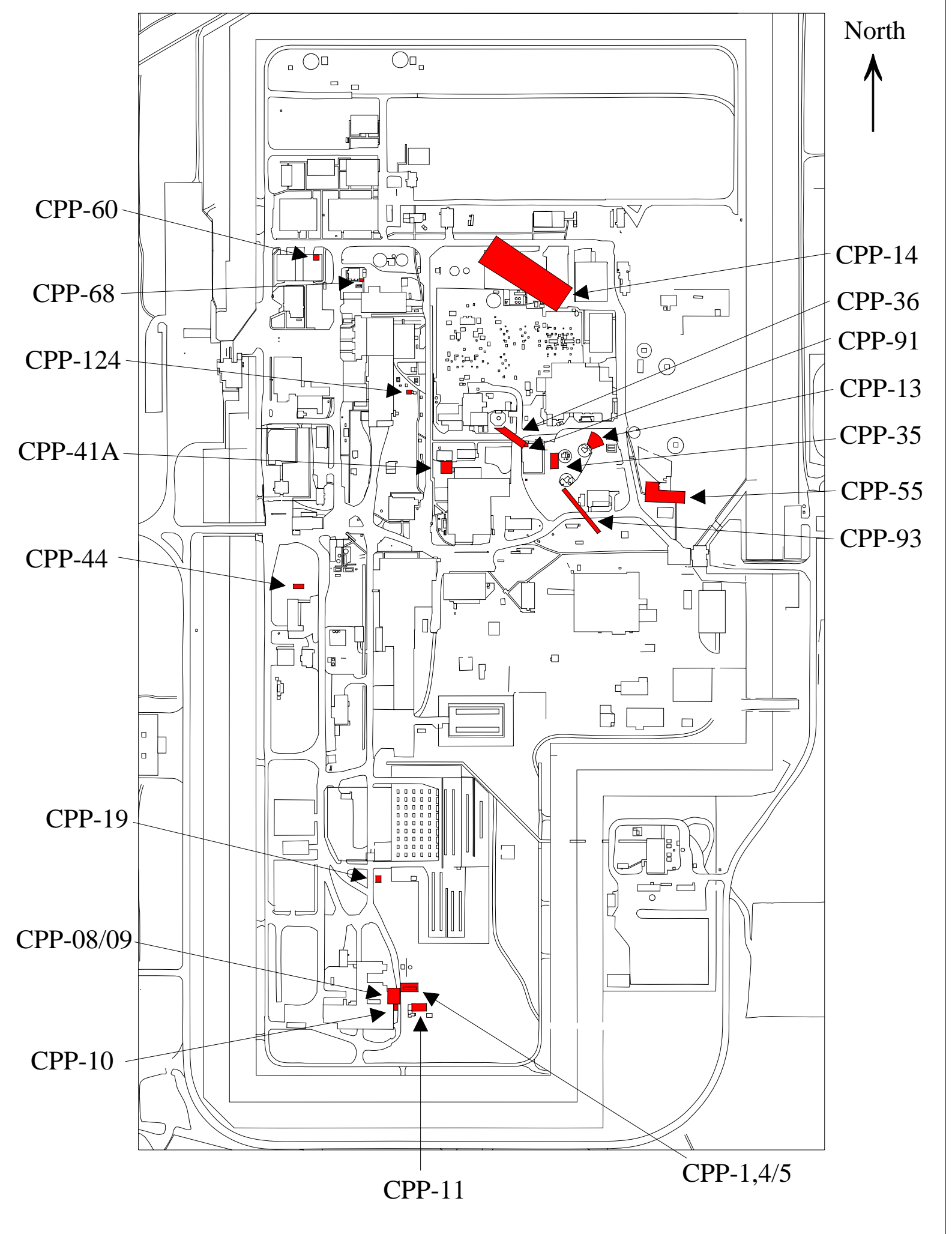

Figure 2-2. Location of OU 3-13, Group 3, Other Surface Soils, Remediation Sets 4-6 (Phase II). 
- $\quad$ CPP-08, Basin Filter System Line Failure

- $\quad$ CPP-09, Contamination at Northeast Corner of CPP-603 South Basin.

Remediation Set 5 (Sites in the Waste Calcine Facility Area with High Environmental Risk Reduction But Significant INTEC Coordination Issues):

- $\quad$ CPP-13, Pressurization of Solid Storage Cyclone Northeast of CPP-633

- $\quad$ CPP-35, CPP-633 Decontamination Spill

- $\quad$ CPP-36, Transfer Line Leak from CPP-633

- $\quad$ CPP-48, French Drain South of CPP-633

- $\quad$ CPP-91, CPP-633 Blower Pit Drain

- $\quad$ CPP-93, Simulated Calcine Disposal Trench.

Remediation Set 6 (Sites with No Planned Anticipated Use and Minimal Environmental Risk Reduction):

- $\quad$ CPP-14, Old Sewage Treatment Plant West of CPP-664

- $\quad$ CPP-41A, Fire Training Pit North of CPP-663, Under Asphalt

- $\quad$ CPP-55, Mercury-Contaminated Area Northwest of CPP-697

- $\quad$ CPP-60, Paint shop at present location of CPP-645

- $\quad$ CPP-68, Abandoned Gasoline Tank CPP VES-UTI-652 North of CPP-606

- $\quad$ CPP-124, Transfer Line Leak West of CPP-750.

Grouping the soil contamination sites into remediation sets was performed in order to organize required work planning and remediation activities. It is here that the need to maintain sites by remediation sets becomes no longer necessary. Sites included in the Phase II RD/RA Work Plan are those not mentioned in the Phase I RD/RA Work Plan and will also include the following:

- $\quad$ New soil contamination sites established by the New Site Identification process

- $\quad$ Soil contamination sites that have been transferred from the Phase I RD/RA Work Plan

- Soil contamination sites that were previously listed as "no action" or "no further action" that need characterization or remedial actions due to additional information being obtained

- $\quad$ Former Group 2, "Soils Under Buildings and Structures” made accessible for remediation (post deactivation and decontamination activities). 


\section{WASTE IDENTIFICATION}

Table 3-1 identifies and describes the waste types that may be generated as a result of OU 3-13, Group 3, remediation activities, management strategies, and the proposed disposition of each waste type. Other waste types might be generated and, if so, will be appropriately designated based on a hazardous waste determination.

Waste as defined by this plan, is materials removed in preparation for and during excavation that have no further use. Examples include: contaminated soil and debris such as concrete pads and foundations, rebar, and abandoned utilities. In areas where contaminated soil is the result of a leaking pipe and/or in areas where abandoned utilities exist in the excavation, the pipe and abandoned utilities, may be handled in a similar fashion as the contaminated soil, is identified as Comprehensive Environmental Response, Compensation and Liability Act (CERCLA) waste to be managed under this plan. Piping and abandoned utilities that extend beyond the excavation (beyond the contaminated soil) is not part of this Phase II remediation activity and is to be managed under the Resource Conservation and Recovery Act (RCRA) and belongs to the RCRA unit where it resides. 
Table 3-1. Waste management during OU 3-13, Group 3, Other Surface Soils, Remediation Sets 4-6 (Phase II) remediation activities.

\begin{tabular}{|c|c|c|c|}
\hline Waste Type & Description & Management Strategy & Disposition \\
\hline Industrial waste (IW) & $\begin{array}{l}\text { Solid waste generated by industrial processes, } \\
\text { manufacturing, and support processes. Certain waste } \\
\text { such as nontraining-related personal protective } \\
\text { equipment (PPE), asbestos, petroleum-contaminated } \\
\text { material such as soil, sand, gravel, or other earthen } \\
\text { material, require a waste-stream-specific, documented } \\
\text { waste determination per the INEEL Waste Acceptance } \\
\text { Criteria (WAC) (DOE-ID 2005b). } \\
\text { Activities that may generate IW include administrative } \\
\text { activities, sampling, and cleanup. }\end{array}$ & $\begin{array}{l}\text { Waste will be characterized as per the } \\
\text { Characterization Plan. } \\
\text { IW will be transported to the Central Facilities } \\
\text { Area (CFA) landfill for disposal. }{ }^{2} \text { Recyclable } \\
\text { and reusable items will be managed under the } \\
\text { INEEL WAC. } \\
\text { Requirements for disposal (described in the } \\
\text { INEEL WAC) must be met. }\end{array}$ & $\begin{array}{l}\text { INL Landfill } \\
\text { Complex (at CFA) or } \\
\text { recycled/reused under } \\
\text { the INL WAC and } \\
\text { this WMP. }\end{array}$ \\
\hline Low-level waste (LLW) & $\begin{array}{l}\text { Radioactive waste that is not high-level radioactive } \\
\text { waste, spent nuclear fuel, transuranic waste, by-product } \\
\text { or naturally occurring radioactive material LLW may } \\
\text { include (but is not limited to) solid sampling and } \\
\text { monitoring materials, tarps, and other material from } \\
\text { staging activities; equipment that cannot be } \\
\text { decontaminated; and other radiologically contaminated } \\
\text { materials such as petroleum-contaminated media } \\
\text { (i.e., soil or other absorbent materials containing } \\
\text { radiological- and petroleum-contaminated materials). } \\
\text { Activities that may generate LLW include sampling and } \\
\text { monitoring, remediation activities, and decontamination. }\end{array}$ & $\begin{array}{l}\text { Waste will be characterized as per the FSP. The } \\
\text { WGS process will document and track LLW. } \\
\text { If LLW are generated during remediation, these } \\
\text { wastes will be disposed of at the ICDF if they } \\
\text { meet the ICDF Complex WAC (DOE-ID- } \\
\text { 2005c). If they do not meet the ICDF WAC, an } \\
\text { alternate disposal facility will be determined. } \\
\text { If liquid wastes are generated during } \\
\text { remediation, these wastes will be disposed of at } \\
\text { the ICDF if they meet the ICDF Complex WAC } \\
\text { (DOE-ID 2005c). If they do not meet the ICDF } \\
\text { Complex WAC, an alternate disposal facility } \\
\text { will be determined. }\end{array}$ & $\begin{array}{l}\text { ICDF landfill (soil } \\
\text { and debris) } \\
\text { ICDF evaporation } \\
\text { pond (liquid) } \\
\text { In the event } \\
\text { wastes do not } \\
\text { meet the ICDF } \\
\text { Complex WAC } \\
\text { (DOE-ID 2005c), } \\
\text { the wastes will be } \\
\text { containerized, } \\
\text { treated, and/or stored, } \\
\text { as necessary or } \\
\text { required, until } \\
\text { appropriate on-Site } \\
\text { or off-Site treatment, } \\
\text { storage, or disposal } \\
\text { is arranged. }\end{array}$ \\
\hline
\end{tabular}


Table 3-1. (continued).

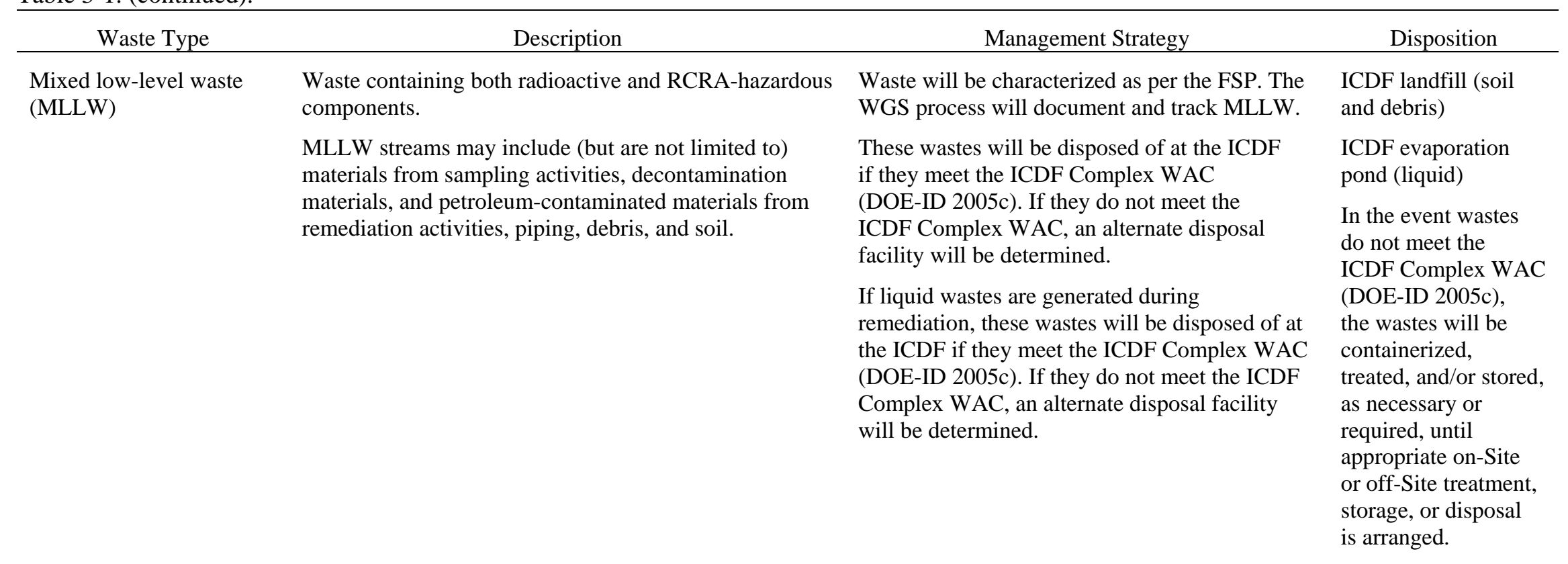

Polychlorinated biphenyl PCB streams may include (but are not limited to) (PCB) waste (including radioactively contaminated PCB waste) materials from sampling and decontamination activities and remediation activities (e.g., PPE, debris, and soil).
Waste will be characterized as per the FSP. The WGS process will document and track PCB waste.

These wastes will be disposed of at the ICDF if they meet the ICDF Complex WAC

(DOE-ID 2005c). If they do not meet the ICDF Complex WAC, an alternate disposal facility will be determined.

\section{ICDF landfill (soil and debris)}

In the event wastes do not meet the ICDF Complex WAC (DOE-ID 2005c), the wastes will be containerized, treated, and/or stored, as necessary or required, until appropriate on-Site or off-Site treatment, storage, or disposal is arranged.

a. Most IW will be sent to the landfill at the CFA for disposal (subject to meeting the INEEL WAC). Industrial waste that does not meet the INEEL WAC for disposal at the CFA landfill will be managed under this WMP. 


\section{GENERAL REQUIREMENTS}

Waste types resulting from the OU 3-13, Group 3, remediation activities may include personal protective equipment (PPE), soil, concrete, metal piping, and other debris. These waste types will be managed in accordance with this WMP.

\subsection{Waste Minimization and Segregation}

Effective waste minimization strategies will be employed during implementation of the remedies. Waste minimization for this project will be accomplished through design and planning to ensure efficient operations that will not generate unnecessary waste. As part of the prejob briefing, emphasis will be placed on waste reduction actions and techniques, and personnel will be encouraged to continuously attempt to improve methods for minimizing waste generation. Practices to be instituted to support waste minimization include, but are not limited to, the following:

- $\quad$ Restricting material entering radiological buffer areas to those needed for work performance

- $\quad$ Substituting recyclable items for nonhazardous and easily-disposed-of items

- $\quad$ Reusing items when practical

- $\quad$ Segregating contaminated from uncontaminated waste

- $\quad$ Reusing soil that meets the OU 3-13 remedial action objectives, as specified in the OU 3-13 Record of Decision (DOE-ID 1999).

\subsection{Characterization Strategy}

Waste generated during remediation of the OU 3-13, Group 3, Other Surface Soils, sites will be characterized using sampling and analytical information (both existing and new) or process knowledge. Initial waste characterization based solely on process knowledge must ensure that the chemical, physical, and radiological properties of the waste are adequately determined. The designation must be accomplished with sufficient accuracy to ensure that subsequent treatment, storage, or disposal of the waste is protective of human health and the environment. Waste characterization is planned prior to starting remediation of several Group 3 sites, as described in the project Characterization Plan (DOE-ID-2005d). This information will be used to prepare a waste profile for the applicable disposal facility in accordance with respective waste acceptance criteria (WAC).

As outlined in Section 3, preliminary classifications have been made of anticipated waste types based on historical knowledge and existing characterization data regarding the source(s) of the expected waste. Subsequent to generation, any or all of the waste may be reclassified. Prior to ultimate disposal, waste may be further characterized to ensure compliance with the applicable disposal facility's WAC. Sampling of the waste for waste profile completion purposes and/or new waste characterization purposes will be performed in accordance with the approach outlined in the project Field Sampling Plan (DOE-ID 2005e). Appropriate and required documentation of waste characterization will be completed in compliance with the applicable WAC. 
An estimation method may be developed to determine the probable distribution of radionuclide and chemical contaminant concentrations on or within debris such as piping and concrete. If employed, this method will use data obtained from known characterized soils from a related or associated process. The contaminant thickness will be determined by practical and relevant field processes of representative portions of the debris in addition to design drawings and process knowledge. Using this information, a mass balance can then be calculated using an assumed or calculated density of the debris and the linear feet of debris present. Upon completion of the mass balance calculations, a waste profile will be developed.

\subsection{INL Waste Management and Disposition}

Waste generated at the INL as a result of CERCLA remedial activities includes hazardous, mixed low-level waste (MLLW), low-level radioactive waste (LLW), and industrial waste (IW) (see Table 3-1). These various types of waste may contain contaminants, such as polychlorinated biphenyls (PCBs) or asbestos, that might be regulated by the Toxic Substance Control Act (TSCA) (40 CFR 763) and the National Emissions Standards for Hazardous Air Pollutants (40 CFR 61.92 and 40 CFR 61.93). This waste may be disposed of at the INL, if it meets the specific facility's WAC. Typically, most of the CERCLA-generated waste will be sent to the ICDF for disposal, although CERCLA-generated IW is generally disposed of at the INL Landfill Complex.

\subsubsection{Waste Planned for Disposal at the ICDF}

Most of the waste anticipated to be generated during implementation of the OU 3-13, Group 3, remediation activities is planned for disposal at the ICDF. This waste will be required to meet the ICDF Complex WAC (DOE-ID 2005c).

\subsubsection{Waste Transported to Non-INL Facilities}

Some of the waste generated during the OU 3-13, Group 3, CERCLA remedial activities could be sent to a treatment, storage, or disposal facility located outside INL boundaries. CERCLA waste that is sent outside INL boundaries for TSD shall meet the requirements of U.S. Department of Transportation, the receiving facility's WAC, and the off-Site rule (40 CFR 300.440) requirements.

\subsubsection{Waste Planned for Disposal at Non-CERCLA INL Facilities}

Appropriateness of a waste disposal option is based on whether a particular waste could reasonably be expected to cause or contribute to an environmentally significant release of hazardous substances from a selected facility. Releases of hazardous substances to the air or groundwater in quantities that could reasonably be expected to pose a significant threat to human health and the environment are considered environmentally significant. Any waste described in this plan that would be reasonably expected to exceed this threshold criterion will be evaluated separately to determine the suitability of the waste for disposal. This particular waste will not be shipped for disposal unless special provisions are made and documented to mitigate the potential for release. The primary list of hazardous substances under CERCLA is contained in 40 CFR 302.4, "Designation of Hazardous Substances.” As the remedial process proceeds and additional information becomes available, reviews that are more detailed will be conducted to ensure that waste planned for specific disposal options meets the detailed WAC for each specific facility. 


\subsubsection{Managing Industrial Waste for Disposal at the INL Landfill Complex}

Industrial waste is solid waste that is neither radioactive nor hazardous. At the INL, industrial waste streams are typically disposed of at the INL Landfill Complex. Many types of CERCLA IW are generated in the area of contamination as a result of material used in a remediation project that the generator believes has not been contaminated with either radioactive or hazardous materials. This absence of contamination is validated by radiation surveys, radiological smears and analysis, and/or visual inspections (visual staining and/or discoloration of soil and/or debris).

A general hazardous waste profile has been prepared for routinely generated IW to document that the waste is neither radioactive nor hazardous. Industrial waste streams that have a higher probability of containing constituents restricted from disposal are considered nonroutine and will undergo a waste-stream-specific hazardous waste determination. This determination is accomplished by sampling; performing radiation and contamination surveys; using process knowledge of the waste-generating process (e.g., determining if the waste was mixed with a listed waste or derived from the treatment, storage, or disposal of a listed waste); and evaluating the composition of the IW. The Waste Generator Services (WGS) evaluates CERCLA IW to determine if the waste meets the IW acceptance criteria. Management of IW is performed in accordance with company procedures.

\subsubsection{Waste Packaging and Transportation}

Before CERCLA waste is transported to the ICDF or an off-Site disposal facility, WGS and Packaging and Transportation Department personnel will be contacted to ensure the waste is properly handled, packaged, labeled, and transported. An alternative is to utilize the INTEC haul road to the ICDF which will eliminate the involvement of the Packaging and Transportation Department. The use of roll-on/roll-off containers and/or articulated trucks should be considered for use as an efficiently alternative to waste containers.

Packaging of waste designated for shipment to ICDF will be in compliance with the OU 3-13 Record of Decision applicable or relevant and appropriate requirements and the ICDF WAC. Appropriate personnel will be consulted prior to generation of any waste to identify proper containment to be used for each waste stream. The CERCLA waste will be packaged in containers that are in good condition, materials are compatible with the waste stored in them, and void spaces in containers are reduced as much as possible. The ICDF Complex management should be consulted prior to the use of containers other than those specified in the ICDF WAC.

For waste containers that are staged or stored, any information not known when waste containers are initially labeled will be added when the information is known. As applicable, WGS personnel will provide IWTS bar codes for containers. Waste labels must be visible, legibly printed or stenciled, and placed on the container in such a manner that the labels and markings are visible during an inspection.

\subsubsection{Managing Waste Information}

Information pertaining to waste characteristics, waste generation and storage locations, disposition plans, and waste shipments for CERCLA MLLW, CERCLA LLW, and nonroutine CERCLA IW generated at the INL is maintained in an electronic database called the IWTS. Material profiles are developed in IWTS to store characterization information that is specific to a particular waste stream. As the waste is generated, information pertaining to individual containers of waste is reported in individual IWTS container profiles. The information in the IWTS material profiles and container profiles is prepared by WGS personnel in accordance with their controls and reviews. 
Waste technical specialists use the information in the IWTS material and container profiles to ensure that CERCLA waste meets the acceptance criteria and to move waste to the ICDF. The IWTS also tracks shipments of waste to various areas or facilities using specific IWTS shipping tasks. Receiving locations, including those located outside the boundaries of the INL, must approve waste shipments before they are shipped. This approval is not documented in the IWTS database but is maintained in a hard copy file with the waste characterization information.

\subsubsection{Staging, Inspection, and Recordkeeping}

Remediation waste types are planned to be actively managed within the work zone. When the containers are filled, the waste will be transferred to the ICDF within five working days. If this timeframe cannot be met and waste staging at the remediation site is necessary, a remediation staging pile will be established in proximity to the remediation site and managed as described below. Waste transferred to the ICDF will be managed in accordance with that facility's work plan.

Remediation waste staging piles may be used to manage waste soil piles or containers of CERCLA mixed waste. Staging piles may be used for a period of up to 24 months unless an extension is provided by the Environmental Protection Agency, Idaho Department of Environmental Quality, and DOE. If waste is staged at the remediation site prior to treatment and disposal, it will be staged in proximity to the remediation site. The staging and inspection of waste generated from this activity will be performed in accordance with established WGS procedures. These records are maintained on an electronic document management system in accordance with company, CERCLA, and National Archive and Records Administration guidelines. The creation and management of waste piles should follow the substantive guidelines as outlined in 40 CFR 264.554, "Staging Piles.”

Containers, if used for waste staging, will be selected to ensure compatibility with the waste being managed. Waste that may be managed in containers includes soils and debris such as equipment and piping. The containers will be managed to enable inspection and ensure that there are no releases associated with their management. 


\section{REFERENCES}

10 CFR 830, Subpart B, 2002, "Safety Basis Requirements," Code of Federal Regulations, Office of the Federal Register, February 2002.

40 CFR 61.92, 2003, “Standard,” Code of Federal Regulations, Office of the Federal Register, September 2003.

40 CFR 61.93, 2003, “Emission monitoring and test procedures,” Code of Federal Regulations, Office of the Federal Register, September 2003.

40 CFR 300.440, 2003, "Procedures for Planning and Implementing Off-Site Response Actions," Code of Federal Regulations, Office of the Federal Register, November 2003.

40 CFR 302.4, 2002, “Designation of Hazardous Substances," Code of Federal Regulations, Office of the Federal Register, September 2002.

40 CFR 763, 2002, “Asbestos,” Code of Federal Regulations, Office of the Federal Register, February 2002.

DOE O 460.1B, 2003, “Packaging and Transportation Safety,” U.S. Department of Energy, April 4, 2003.

DOE-ID, 1991, Federal Facility Agreement and Consent Order for the Idaho National Engineering Laboratory, U.S. Department of Energy Idaho Field Office; U.S. Environmental Protection Agency; Region 10; State of Idaho Department of Health \& Welfare, December 1991.

DOE-ID, 1999, Final Record of Decision, Idaho Nuclear Technology and Engineering Center, Operable Unit 3-13, DOE/ID-10660, Rev. 0, U.S. Department of Energy Idaho Operations Office, October 1999.

DOE-ID, 2003, ICDF Complex Operations Waste Management Plan, DOE/ID-10886, Rev. 0, U.S. Department of Energy Idaho Operations Office, February 2003.

DOE-ID, 2005a, Operable Unit 3-13, Group 3, Other Surface Soils Remediation Sets 4-6 (Phase II) Remedial Design/Remedial Action Work Plan, DOE/ID-11254, Rev. 0, U.S. Department of Energy Idaho Operations Office, 2005.

DOE-ID, 2005b, Idaho National Engineering and Environmental Laboratory Waste Acceptance Criteria, DOE/ID-01-10381, Rev. 21, U.S. Department of Energy Idaho Operations Office, January 2005.

DOE-ID, 2005c, ICDF Complex Waste Acceptance Criteria, DOE/ID-10881, Rev. 2, U.S. Department of Energy Idaho Operations Office, July 2005.

DOE-ID, 2005d, Operable Unit 3-13, Group 3, Other Surface Soils Remediation Sets 4-6 (Phase II) Characterization Plan, DOE/ID-11257, Rev. 0, U.S. Department of Energy Idaho Operations Office, 2005.

DOE-ID, 2005e, Operable Unit 3-13, Group 3, Other Surface Soils Remediation Sets 4-6 (Phase II) Field Sampling Plan, DOE/ID-11256, Rev. 0, U.S. Department of Energy Idaho Operations Office, 2005. 